\title{
Analisis Evaluasi Keberlanjutan E-Filling di Kota Palembang
}

\author{
Dewi Sartika ${ }^{1}$, Imelda Saluza ${ }^{2)}$ \\ ${ }^{1)}$ Jurusan Manajemen Informatika, Universitas Indo Global Mandiri \\ 2) Jurusan Teknik Informatika Fakultas Ilmu Komputer, Universitas Indo Global Mandiri \\ Jalan Jendral Sudirman No. 629 KM 4 Palembang Kode Pos 30129 \\ Email : dewi.sartika@uigm.ac.id ${ }^{1)}$, imeldasaluza@uigm.ac.id ${ }^{2)}$
}

\begin{abstract}
DJP continues to optimize the collection of tax returns by facilitating a technology-based tax service system, one of which is e-filing that has been running since 2016. However, e-filing turned out to have less influence on the delivery of Tax Returns (SPT) as reflected in the electronic SPT monitoring data that only met $78 \%$ of the 2017 target. This is caused by various problems that arise during the use of e-filing such as individual technology capabilities, loss of efin, forgetting DJP Online account passwords to lack of awareness about the importance of submitting SPT. Problems encounter during the use of e-filing are the basis for evaluating the continued use of e-filling in Palembang. The development of a conceptual model was conducted to evaluate the sustainability of the use of e-filing. The development of a conceptual model basically has a scarcity of supporting theories used and has a complex model. To overcome this problem, Partial Least Squares (PLS) Structural Equation Model (SEM) could be applied to. The results of data analysis found that information quality and service quality did not have a positive influence on the sustainability of the use of e-filing and the level of correlation between information quality, system quality, service quality, and individual ability was still small towards the sustainability of the use of e-filing. The findings of this research are very important for the KPP Pratama in Palembang to analyze the sustainability of the use of e-filing that has been proven empirically, multidimensional and in a specific context. This knowledge could be used as a reference to improve overall quality of taxation for the sake of sustainable use of e-filing.
\end{abstract}

Keywords : SPT, e-filing, PLS SEM

\begin{abstract}
Abstrak
DJP terus berupaya mengoptimalkan pengumpulan Surat Pemberitahuan Tahunan (SPT) pajak dengan memfasilitasi sistem pelayanan perpajakan berbasis teknologi, salah satunya adalah e-filing yang telah berjalan sejak tahun 2016. Namun, e-filing ternyata kurang berpengaruh terhadap penyampaian SPT yang tergambar pada data hasil monitoring SPT elektronik yang hanya memenuhi 78\% dari target sasaran tahun 2017. Hal ini disebabkan oleh berbagai masalah yang muncul selama pemanfaatan e-filing seperti kemampuan teknologi individu, kehilangan efin, lupa password akun DJP Online hingga kurangnya kesadaran tentang pentingnya penyampaian SPT. Permasalahan selama penggunaan efiling menjadi dasar untuk melakukan evaluasi terhadap keberlangsungan penggunaan e-filling di Palembang. Pengembangan model konseptual dilakukan untuk mengevaluasi keberlanjutan penggunaan e-filing. Pengembangan model konseptual pada dasarnya memiliki kelangkaan teori-teori pendukung yang digunakan dan memiliki model yang kompleks. Untuk mengatasi masalah ini dapat menggunakan Partial Least Squares (PLS) Structural Equation Model (SEM). Hasil analisis data mendapatkan temuan bahwa kualitas informasi dan kualitas layanan tidak memiliki pengaruh positif terhadap keberlanjutan penggunaan e-filing dan tingkat korelasi antara kualitas informasi, kualitas system, kualitas layanan, dan kemampuan individual masih kecil terhadap keberlanjutan penggunaan e-filing. Temuan peneliti ini sangat penting bagi pihak KPP Pratama kota Palembang untuk menganalisa keberlanjutan penggunaan efiling yang telah dibuktikan secara empiris, multidimensional dan konteks yang spesifik. Pengetahuan ini dapat dapat menjadi acuan untuk meningkatkan kualitas secara keseluruhan demi keberlanjutan penggunaan e-filing.
\end{abstract}

Kata kunci : SPT, e-filing, PLS SEM, 


\section{Pendahuluan}

Berdasarkan Undang-Undang RI Nomor 28 Tahun 2007 tentang ketentuan umum dan tata cara perpajakan pasal 1 yang berbunyi pajak adalah konstribusi wajib kepada negara yang terutang oleh orang pribadi atau badan yang bersifat memaksa berdasarkan undangundang, dengan tidak mendapatkan imbalan secara langsung dan digunakan untuk keperluan negara bagi sebesar-besarnya kemakmuran rakyat. Seperti yang dijelaskan pada Undang-Undang RI Nomor 28 Tahun 2007 tentang ketentuan umum dan tata cara perpajakan pasal 1 yang berbunyi setiap wajib pajak wajib mengisi surat pemberitahuan dengan benar, lengkap dan jelas dalam bahasa Indonesia dengan menggunakan huruf latin, angka arab, satuan mata uang rupiah dan menandatangani serta menyampaikannya ke kantor direktorat pajak tempat wajib pajak terdaftar atau dikukuhkan atau tempat lain yang ditetapkan oleh Direktur Jendral Pajak (DJP).

DJP terus berupaya mengoptimalkan pengumpulan Surat Pemberitahuan Tahunan (SPT) pajak dengan memfasilitasi sistem pelayanan perpajakan berbasis teknologi, salah satunya adalah e-filing yang telah berjalan sejak tahun 2016. Harapan DJP dengan memberikan kemudahan dalam penyampaian SPT dapat mendorong semua wajib pajak dan pihak terkait dalam menjalankan hak dan kewajibannya sesuai undangundang yang berlaku. Berdasarkan peraturan direktur jendral pajak Nomor Per-01/PJ/2016 tentang tata cara penerimaan dan pengolahan SPT, e-filing adalah suatu cara penyampaian SPT secara elektronik yang dilakukan secara online dan real time melalui internet pada website DJP atau penyedia layanan SPT elektronik atau Application Service Provider (ASP). Namun di tahun 2017 ternyata penyampaian SPT hanya memenuhi 78\% berdasarkan hasil monitoring SPT elektronik pihak KPP Pratama Palembang. Hal ini disebabkan oleh berbagai masalah yang muncul selama pemanfaatan $e$-filing seperti kemampuan teknologi individu, kehilangan efin, lupa password akun DJP Online hingga kurangnya kesadaran tentang pentingnya penyampaian SPT.

Masalah-masalah yang ditemukan selama penggunaan e-filing menjadi dasar untuk melakukan evaluasi terhadap keberlangsungan penggunaan $e$-filling di Palembang. Pengembangan model konseptual dilakukan dengan menggabungkan model D\&M yang digunakan untuk mengukur kualitas sistem dan kualitas informasi, sedangkan untuk mengukur kualitas layanan digunakan model E-S-Qual. Selanjutnya Hasil penggabungan kedua model tersebut akan ditambahkan satu peubah yaitu individual abilities (kemampuan individu). Hasil data valid yang berhasil dikumpulkan selanjutnya akan dianalisis menggunakan teknik pemodelan statistik Structural Equation Model (SEM).
A. Tinjauan Pustaka
1. Pengembangan Model
a. Model McLean dan Delone

Model McLean dan Delone merupakan model yang dikembangkan pada tahun 1992 untuk mengukur kesuksesan suatu sistem informasi melalui pemahaman tentang sistem informasi (SI) dan dampaknya terhadap suatu organisasi dan terus mengalami perkembangan dengan penambahan faktor yaitu kualitas layanan namun jika berupa SI pemerintahan maka net benefits akan berupa kelanjutan dan meningkatnya penggunaan SI seperti telihat pada gambar 2.1 berikut

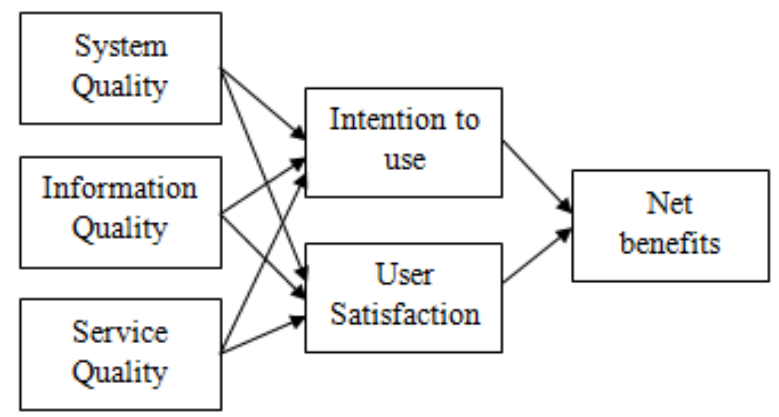

Gambar 1. Pengembangan Model Mclean dan Delone

\section{b. Model E-S-Qual}

Pada awalnya Zeithaml, dkk pada tahun 2000 mengembangkan suatu kerangka konseptual untuk mengevaluasi e-service quality pada e-commerce (Zeithaml, Parasuraman, and Malhotra). Kemudian kerangka konseptual tersebut terus dikembangkan, sehingga menghasilkan suatu model E-S-Qual skala multi item yang dikembangkan oleh Parasuraman, dkk pada tahun 2005. Model E-S-Qual skala multi item merupakan suatu model yang digunakan untuk mengukur kualitas layanan elektronik dengan memasukkan harapan dari pengguna situs dengan skala multi item (Parasuratman).

Pada awalnya model E-S-Qual skala multi item terdiri dari 22 item dengan 4 dimensi, yaitu:

1. Efficiency: kemudahan dan kecepatan mengakses dan menggunakan situs.

2. Fulfillment: sejauh mana janji pengelola layanan terhadap penyampaian dan ketersediaan layanan terpenuhi.

3. System availability: kegunaan teknis fungsi yang benar.

4. Privacy: tingkatan dimana situs aman serta mampu melindungi informasi dari pengguna.

Namun, menurut Parasuraman 22 item tersebut hanya terbatas pada layanan non operasional yang tidak banyak diketahui oleh pengguna. Oleh karenanya dilakukan pengembangan untuk menyempurnakan model $E$-S-Qual skala multi item dengan menambah skala item sebanyak 11 item dengan 3 dimensi yaitu:

1. Responsiveness: kecepatan respon dalam manangani masalah atau pertanyaan.

2. Compensation: tingkatan dimana system memberikan kompensasi/ ganti rugi kepada pengguna terhadap masalah yang muncul.

3. Contact: ketersediaan bantuan melalui telepon atau online. 
Tiga dimensi di atas lebih difokuskan untuk menangani permasalahan-permasalahan atau pertanyaan layanan, dan bermanfaaat bagi pengguna layanan yang jarang mengakses situs.

\section{Structural Equation Model (SEM)}

Pemodelan persamaan struktural sering disebut dengan Structural Equation Model (SEM) merupakan suatu teknik pemodelan statistik yang merupakan kombinasi dari analisis faktor (confirmatory factor analysis), model struktural dan regresi atau analisis jalur (path analysis). Dalam penerapannya, SEM sangat membantu membantu penelitian yang digambarkan oleh faktor-faktor model penelitian yang melibatkan peubah laten.

Menurut Byrne, SEM meberikan tiga keuntungan dalam penggunaannya. Pertama, SEM sangat cocok digunakan dalam menganalisis data dengan tujuan melakukan inferensial sementara analisis multivariat yang lain hanya cocok untuk menganalisis data dengan tujuan melakukan deskriptif terhadap data. Kedua, analisis multivariat biasa tidak mampu menilai dan memperbaiki error dalam pengukuran sedangkan SEM memberikan perkiraan eksplisit dari parameter error (Byrne). Hal ini terjadi karena model multivariat biasa yang berbasis pada analisis regresi atau model linier umum mengabaikan error yang diperoleh, sehingga menyebabkan ketidakakuratan dalam analisis data. Ketiga, analisis data menggunakan metode lain hanya berdasarkan pengukuran yang diamati saja sedangkan SEM merupakan kombinasi dari beberapa metode.

Menurut Bollen, SEM secara umum terdiri dari dua model. Model yang pertama adalah model struktural (Structural Model) (Bollen):

$$
\eta_{(m x 1)}=\mathrm{B}_{(m x m)} \eta_{(m x 1)}+\Gamma_{(m x n)} \xi_{(n x 1)}+\zeta_{(m x 1)}
$$

Model ini mengadaptasi model persamaan simultan (analisis regresi berganda) pada ekonometri. Pada ekonometri semua variabel merupakan variabel-variabel terukur/ teramati/ manifest (measured/ observe/ manifest variables), pada model ini variabel-variabelnya merupakan konstruk atau variabel laten atau tidak terukur/ tidak teramati (laten variables/ unobserved variables).

\section{Research methodology}

a. Model Konseptual

Penelitian ini melakukan pengembangan model konseptual berdasarkan model Mclean dan Delone dan model E-S-Qual. Pengembangan model konseptual digunakan untuk mengevaluasi keberlanjutan e-filing di Palembang, serta mengetahui faktor-faktor yang perlu ditingkatkan agar e-filing dapat terus digunakan untuk melakukan pelaporan SPT pajak perorangan. Lokasi penelitian dilakukan di kota Palembang dan data diperoleh dari kantor Pajak Pratama kota Palembang, yakni Pratama Palembang Ilir Timur, Pratama Palembang Seberang Ulu, Pratama Ilir Barat dan Madya
Palembang. Model konseptual dari penelitian ini terlihat pada gambar 2.2 berikut:

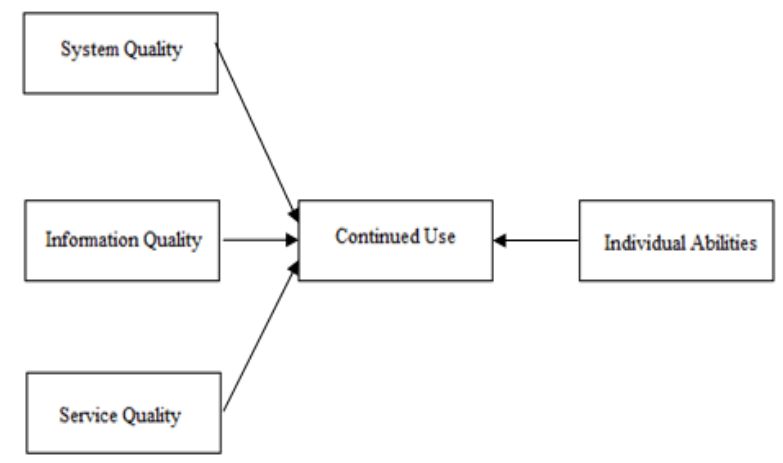

Gambar 2. Model Konseptual

Pengembangan model Evaluasi Keberlanjutan efiling terdiri dari tiga tingkatan, tingkatan pertama terdiri dari accuracy, timeliness, relevance, understand ability, completeness, functionality, dependability, ease of use, usefullness, efficiency, fullfillment, privacy, system availability, responsifness, compensation, contact dan individual abilities. Tingkatan kedua terdiri dari information quality, system quality, services quality dan individual ability, untuk tingkatan ketiga terdiri dari continued use.

\section{b. Pengumpulan Data}

Data yang digunakan pada penelitian ini merupakan data primer yang diperoleh melalui pengisian kuesioner yang disebarkan kepada responden dengan menggunakan teknik simple random sampling. Responden yang dimaksud merupakan wajib pajak yang memiliki NPWP dan pernah menggunakan e-filing guna melaporkan Surat Pemberitahuan Tahunan (SPT) perorangan.

\section{c. Persiapan Data}

Persiapan data merupakan langkah awal yang digunakan saat akan melakukan analisis data. Persiapan data yang digunakan pada penelitian meliputi analisis deskriptif, distribusi data dan kolinearitas. Analisis deskriptif merupakan analisis yang memberikan gambaran suatu data terhadap objek atau data yang diteliti baik berkelompok ataupun tidak berkelompok (Riduwan). Distribusi data dilakukan untuk melihat gambaran distribusi frekuensi (cacah responden) atau distribusi normal. Distribusi normal bersifat simetri terhadap nilai rata-rata (mean) dari data yang digambarkan pada distribusi normal dan pesebaran data ditentukan oleh simpangan baku. Kolinearitas terjadi jika peubah bebas saling berkorelasi dan jika lebih dari satu hubungan tersebut terjadi maka dinamakan multikolinearitas. Kolinearitas dapat dideteksi melalui nilai Variance Inflator Factor (VIF). Menurut Hair, nilai Variance Inflator Factor (VIF) yang lebih kecil dari 10 menunjukkan tidak terdapat persoalan kolinearitas. Persiapan data dilakukan dengan menggunakan Statistical Product and Service Solutions atau SPSS. 


\section{d. Analisis data}

Partial Least Square (PLS) Structural Equation Model (SEM) bertujuan untuk mengkaji hubungan yang bersifat prediktif antara peubah laten/kontruk dengan melihat hubungan atau pengaruh antar peubah laten/konstruk tersebut dan PLS SEM sangat tepat digunakan pada penelitian yang bertujuan untuk pengembangan suatu model (Imam Ghozali). Analisis data pada penelitian ini terdiri dari lima tahapan yakni, merancang model, konstruksi diagram jalur, konversi ke persamaan, estimasi, evaluasi model.

\section{Pembahasan}

\section{A. Hasil Uji Coba Instrumen}

Penelitian ini menggunakan responden yakni pelapor Surat Pemberitahuan Tahunan (SPT) yang diberikan oleh KPP Pratama dan melakukan pelaporan menggunakan efiling, dengan menggunakan rumus Slovin dieproleh jumlah sampel sebanyak 86 responden yang tersebar di kota Palembang dan berada pada tiga kantor KPP Pratama, yaitu KPP Pratama Ilir Barat, KPP Pratama Ilir Timur dan KPP Pratama Seberang Ulu dalam melakukan uji coba instrumen.

Tabel 1. Hasil Uji Coba Instrumen Penelitian

\begin{tabular}{|c|c|c|c|c|c|}
\hline \multicolumn{3}{|c|}{ Ug Vasdasas } & \multicolumn{3}{|c|}{ UjRobas } \\
\hline Indikator & $\begin{array}{c}\text { Croubrach's } \\
\text { Aliphas }\end{array}$ & Keputwas & & $\begin{array}{l}\text { Average } \\
\text { Variase }\end{array}$ & \\
\hline A. & 1,000 & Valis & Intikator & $\begin{array}{c}\text { Everased } \\
\text { (AVE) }\end{array}$ & Keputusu \\
\hline $\mathrm{Cl}$ & 0.799 & Valis & & $\begin{array}{c}(A \backslash \mathrm{E}) \\
1000\end{array}$ & Rofiget 1 \\
\hline $\mathrm{C} 3$ & 0.859 & Valid & Acexacy & 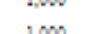 & Refabe! \\
\hline com & 1,000 & Valit & Compeasatisa & 1,000 & Tids: \\
\hline coN1 & 0.943 & Valis & Complatestz & 0.654 & Retabe! \\
\hline CON2 & 0.743 & Valif & & & Tits: \\
\hline CON3 & 0.742 & Valis & Coctast & 0.654 & Reliabe! \\
\hline cU: & 0.953 & Valid & Coctimed Un: & 0.498 & $\begin{array}{l}\text { Tifsi: } \\
\text { Relabe! }\end{array}$ \\
\hline CU3 & 0.260 & Valis & Dependabily & 1,000 & Refiabe! \\
\hline D2 & 1,000 & Valid & & & Tidas: \\
\hline EF & 1,000 & Valid & Ens Uns & 0.291 & Reliabe! \\
\hline EU: & 0.357 & Titsevalid & Effuteary & 1,000 & Reliabe! \\
\hline EU: & .0529 & Tisas: Valit & Folfilment: & 0.734 & Reliabe! \\
\hline EU3 & 0.657 & Titas: Valid & & & Tits: \\
\hline EU4 4 & .0565 & Tidsevalid & Fuatisesify & 0.460 & Retiabs! \\
\hline F1. & .0 .753 & Titsevalid & $\begin{array}{l}\text { Iadividse! } \\
\text { Abdita: }\end{array}$ & 0.48 & $\begin{array}{l}\text { Tidsi: } \\
\text { Refiabel }\end{array}$ \\
\hline F2 & 0.694 & Tisat:valis & Information & & Relabe! \\
\hline $\mathrm{F}$ & 0.587 & Titse:Valid & Syrem & 1,000 & \\
\hline FUL1 & 0.993 & Valit & f & & Tids: \\
\hline Fut:2 & 0.747 & valis & 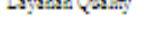 & 0.436 & $\begin{array}{l}\text { Refiabe! } \\
\text { Titat }\end{array}$ \\
\hline IAI & 0.991 & valis & Prinacy & 0.57 & Retiabe! \\
\hline IA2 & 0.852 & vais & 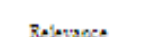 & & Tits: \\
\hline IA3 & 0.352 & Tisas Valid & Re:atast & 0.657 & Reabe! \\
\hline 19! & 1,000 & $\begin{array}{c}\text { Thas vald } \\
\text { Vald }\end{array}$ & Reypodineas: & 0.757 & Rasese \\
\hline LQ1 & 0.304 & Titak Valid & Syan Quity & 0.576 & Tids: \\
\hline LQ2 & 0.905 & $\begin{array}{c}\text { Titsevalis } \\
\text { Valis }\end{array}$ & Timeliness & 1,000 & Relabe! \\
\hline ?2 & 0.941 & $\begin{array}{l}\text { Valis } \\
\text { Valid }\end{array}$ & & & Tids: \\
\hline P3 & 0.570 & $\begin{array}{l}\text { Valid } \\
\text { Vais }\end{array}$ & Undersandabiling & 0.603 & Reiabe! \\
\hline 24 & 0.457 & Valid & Unfuhen & 1,000 & Reliabe! \\
\hline $\mathrm{R} 2$ & 0.742 & Tidsevalid & & & \\
\hline $\mathrm{R3}$ & 0.908 & Vasit & & & \\
\hline RES1 & 0.735 & Viste & & & \\
\hline RES2 & 0.995 & $\begin{array}{l}\text { Valis } \\
y, i s\end{array}$ & & & \\
\hline SQ1 & 0.760 & $\begin{array}{l}\text { vald } \\
\text { valis }\end{array}$ & & & \\
\hline$\$ Q 2$ & 0.788 & Vaits & & & \\
\hline$T 2$ & 1,000 & Valis & & & \\
\hline U3 & 1,000 & Valis & & & \\
\hline UN2 & .0590 & Tids: Valid & & & \\
\hline uns & 0.980 & valit & & & \\
\hline
\end{tabular}

Dari tabel hasil uji coba instrumen yang dilakukan terdapat indikator yang tidak valid dan tidak reliabel sehingga indikator-indikator tersebut tidak digunakan lagi pada uji selanjutnya. Dari hasil analisa yang dilakukan ternyata terdapat beberapa masalah dalam mengumpulkan data dari responden, antara lain kurangnya ketelitian dalam melakukan pengisian instrumen seperti terdapat pertanyaan yang tidak dijawab atau adanya pertanyaan membuat keraguan responden dalam menanggapi pertanyaan.

\section{B. Hasil Analisis Uji Instrumen}

Analisis Konstruksi Jalur

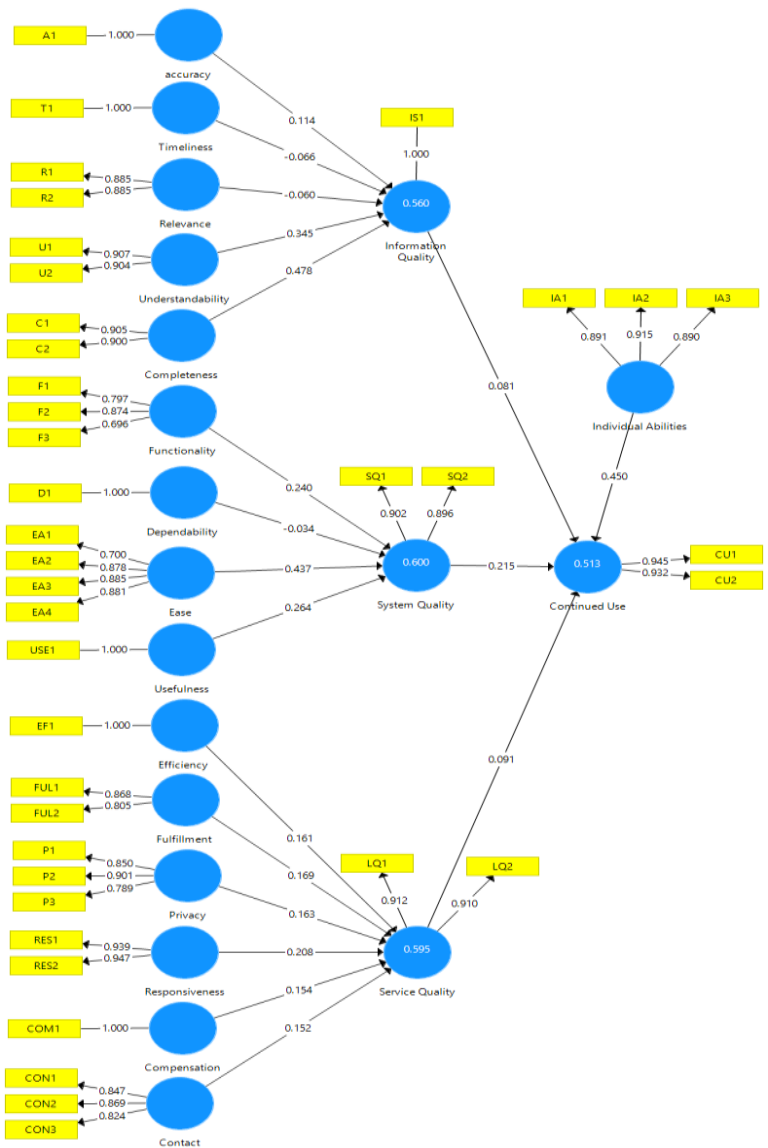

Gambar 3. Diagram Jalur Uji Coba Instrumen

Konstruksi diagram jalur pada uji coba instrumen dapat dilihat dari gambar 4.1 terlihat bahwa pada model pengukuran/outer model arah hubungan adalah dari variabel laten/ konstruk menuju indikator, hal ini dilakukan karena pada penelitian ini akan dilakukan karena peneliti akan mengembangkan suatu model dalam mengevaluasi keberlanjutan e-filing. Sedangkan pada model struktural terjadi hubungan yang menunjukkan arah dari peubah laten/konstruk eksogen menuju ke variabel laten/konstruk endogen.

\section{Konversi Persamaan}

Tahapan konversi ke persamaan merupakan tahapan mengubah model yang ada ke dalam suatu persamaan 
matematis. Untuk model pengukuran/outer model pada indikator diperoleh persamaan berikut:

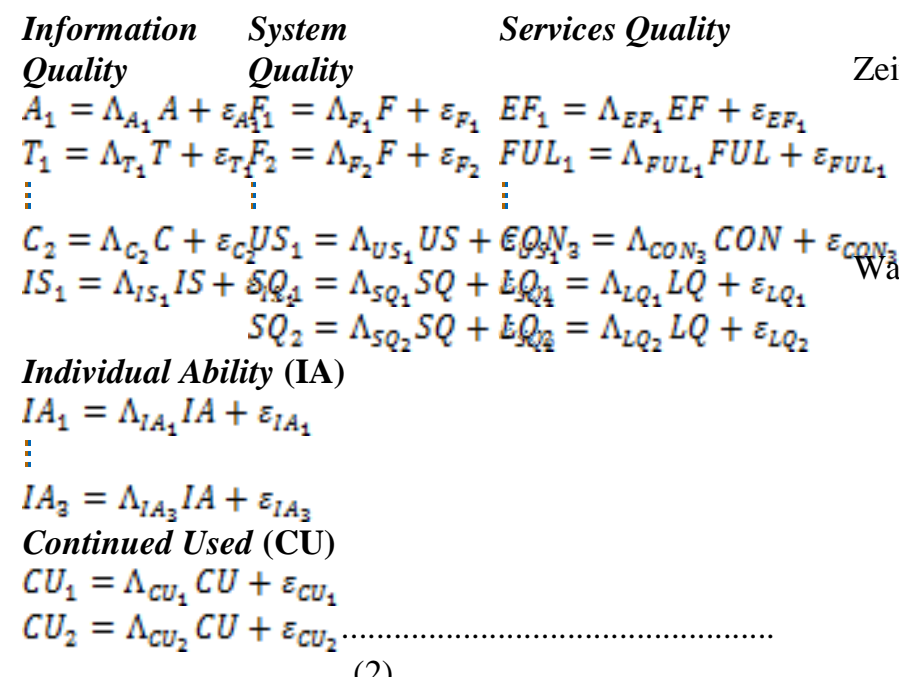

AMOS. N.p., 2010. Web.

Parasuratman, A. "A Multiple-Item Scale for Assessing Electronic Service Quality." Journal of Service Research 7.X . 2005: 1-21. Web.

Zeithaml, V. a., a. Parasuraman, and a. Malhotra. "Service Quality Delivery through Web Sites: A Critical Review of Extant Knowledge." Journal of the Academy of Marketing Science 30.4. 2002: 362-375. Web.

ângpipatwong, S., Chutimaskul, W., \& Papasratorn, B. 2009. Quality Enhancing the Continued Use of EGovernment Websites: Evidance from E-Citizens of Thailand. International Journal of Electronic Govermment Research, 5(March), 19-35.

sedangkan persamaan untuk model struktural/inner model diberikan persamaan berikut:

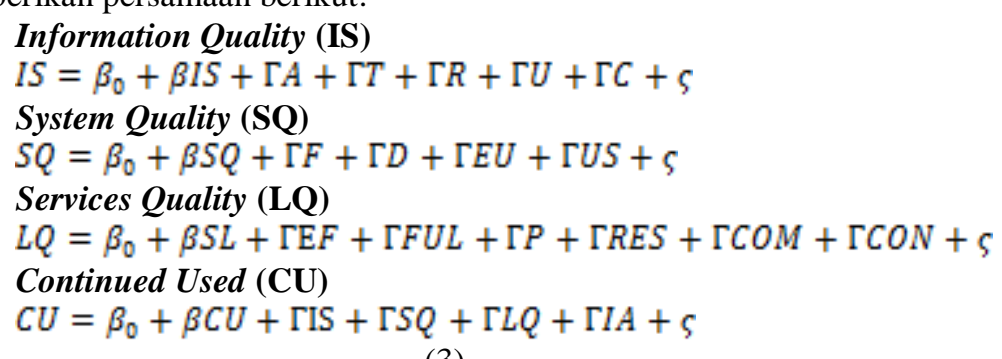

\section{Kesimpulan}

Model evaluasi pengembangan keberlanjutan e-filing dapat dimanfaatkan untuk menganalisa, menilai dalam rangka peningkatan kualitas e-filing sebagai fasilitas untuk melaporkan pajak. Hasil analisis data menunjukkan adanya beberapa indikator dan variabel yang tidak valid serta reliabel saat diuji coba mengukur respon yang diberikan oleh responden. Dari diagram jalur serta persamaan matematis mengahasilkan beberapa indikator yang tampak jelas memiliki pengaruh yang kecil terhadap variabel laten exogenous dan endogenous. Temuan peneliti ini sangat penting bagi pihak KPP Pratama kota Palembang untuk menganalisa keberlanjutan penggunaan e-filing yang telah dibuktikan secara empiris, multidimensional dan konteks yang spesifik. Pengetahuan ini dapat dapat menjadi acuan untuk meningkatkan kualitas secara keseluruhan demi keberlanjutan penggunaan e-filing.

\section{Daftar Pustaka}

Bollen, Kenneth A. "A New Incremental Fit Index for General Structural Equation Models.” Sociological Methods \& Research 17. 1989: n. pag. Print.

Byrne, Barbara M. Structural Equation Modeling with 